УДК 621.039.51.15

\title{
SET UP OF A DETERMINISTIC CALCULATION MODEL FOR THE ANALYSIS OF FUSION-FISSION HYBRID SYSTEMS
}

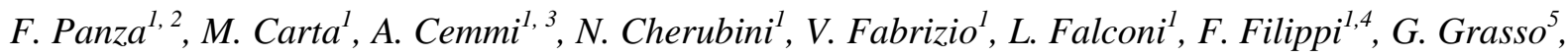 \\ F.P. Orsitto ${ }^{1}$, V. Peluso
}

\author{
${ }^{l}$ ENEA - Dipartimento Fusione e Tecnologie per la Sicurezza Nucleare - Divisione Tecnologie, Impianti e Materiali Per la Fissione \\ Nucleare, Roma, Italy \\ ${ }^{2}$ Istituto Nazionale di Fisica Nucleare - Sezione di Genova, Genova, Italy \\ ${ }^{3}$ Istituto Nazionale di Fisica Nucleare - Sezione di Roma Tre, Roma, Italy \\ ${ }^{4}$ Istituto Nazionale di Fisica Nucleare -Laboratori Nazionali di Frascati, Frascati, Italy \\ ${ }^{5}$ ENEA - Dipartimento Fusione e Tecnologie per la Sicurezza Nucleare - Divisione Sicurezza e Sostenibilità del Nucleare, Bologna, \\ Italy
}

A simplified Fusion-Fission Hybrid System (FFHS) deterministic calculation model has been developed in order to study the coupling between a fusion machine and a subcritical fission system. Monte-Carlo (MC) codes are very flexible and they have to be considered as reference calculation tools for complex systems like FFHS. On the other hand, deterministic codes can provide, in shorter calculation time respect to MC codes, parametric and sensitivity analysis, also by exploiting General Perturbation Theory (GPT) methodologies, which can usefully support the global FFHS theoretical analysis. This work describes the comparison between the results obtained for a simplified FFHS model by using a MC code (MCNP6.1, MC N-Particle) and a deterministic code (ERANOS). In particular, in this preliminary study, integral parameters like $k_{\text {eff }}$, thermal power, neutron fluxes and some key reaction rate profiles, will be compared. If the comparison between the two mentioned codes will give encouraging results further, more refined, studies will be performed in order to consider deterministic codes as a powerful workhorse for the FFHS analysis, including time dependent analysis devoted to transient and reactivity monitoring issues.

Key words: FFHS, Monte-Carlo codes, deterministic codes.

DOI: $10.21517 / 0202-3822-2021-44-2-42-46$

\section{РАЗРАБОТКА ДЕТЕРМИНИРОВАННОЙ РАСЧЁТНОЙ МОДЕЛИ ДЛЯ АНАЛИЗА ГИБРИДНЫХ СИСТЕМ СИНТЕЗА-ДЕЛЕНИЯ}

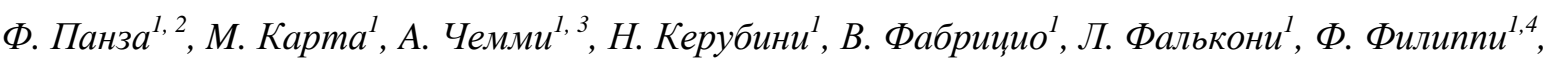 \\ Г. Грассо, Ф.П. Орситто, В. Пелузо
}

\begin{abstract}
${ }^{1}$ Национальное агентство по новым технологиям, энергии и устойчивому развитию (ENEA), Отделение термоядерного синтеза и технологий ядерной безопасности, Отдел технологий, установок и материалов для ядерного деления, Рим, Италия

${ }^{2}$ Национальный институт ядерной физики, Генуэзское отделение, Генуя, Италия

${ }^{3}$ Национальный институт ядерной физики, Третье римское отделение, Рим, Италия

${ }^{4}$ Национальный институт ядерной физики, Начиональная лаборатория Фраскати, Фраскати, Италия

${ }^{5}$ ENEA, Отделение термоядерного синтеза и технологий ядерной безопасности, Отдел ядерной безопасности и устойчивого развития, Болонья, Италия
\end{abstract}

\begin{abstract}
Для изучения связи между термоядерной установкой и докритической зоной деления была разработана упрощённая детерминированная расчётная модель гибридной системы синтеза-деления (ГССД). Вычислительные программы Монте-Карло (МК) очень гибки и могут рассматриваться как эталонные инструменты расчёта для сложных систем, таких как ГССД. Детерминированные коды могут за более короткое расчётное время, чем программы МК, выполнить параметрический анализ и анализ чувствительности, также используя методы общей теории возмущений (ОТВ), ускорив этим глобальный теоретический анализ ГССД. В данной работе сравниваются результаты, полученные для упрощённой модели ГССД с использованием кода МК (MCNP6.1, Monte-Carlo N-Particle) и детерминированного кода (ERANOS). В частности, в этом предварительном исследовании сравниваются интегральные параметры: $k_{\text {эф}}$, тепловая мощность, потоки нейтронов и некоторые ключевые профили скорости ядерных реакций. Если сравнение результатов, полученных двумя упомянутыми кодами, будет признано обнадёживающим, в дальнейшем будут проведены уточнённые исследования с целью обосновать использование детерминированных кодов в качестве эффективного средства для анализа ГССД, включая зависящий от времени анализ мониторинга переходных процессов и реактивности.
\end{abstract}

Ключевые слова: гибридная программа синтеза-деления, вычислительные программы Монте-Карло, детерминированные коды.

\section{INTRODUCTION}

A Fusion-Fission Hybrid System (FFHS) [1], obtained by coupling a fusion machine and a sub-critical fission system, could, in principle, have some potential applications, including fission nuclear waste management. 
This system can be seen as an Accelerator Driven System (ADS), where a subcritical fission blanket is driven by neutrons emerging from the fusion plasma instead of coming from an accelerator.

With a view to the component-by-component evaluation strategy extensively used in the ADS studies [2], one can separately analyze the FFHS's two main characteristics: the intensive neutron source and the subcritical fission blanket.

MC codes are very flexible and can be considered as reference calculation tools to deal with complex systems, such as FFHSs. On the other hand, deterministic codes can be a quicker alternative to MC codes when it comes to doing a parametric and sensitivity analysis, especially using the GPT-based methodologies [3], which are useful in supporting the global FFHS theoretical analysis.

In this work we compare, in a preliminary way, results obtained for a simplified FFHS model using a MC code (MCNP6.1) [4] and a deterministic code (ERANOS). [5]. In particular, we compare integral parameters like $k_{\text {eff }}$, neutron fluxes and some key reaction rate profiles.

\section{CALCULATION MODEL SET-UP}

A simplified cylindrical 2D-RZ model, with different homogenized coaxial zones, has been defined to study the subcritical fission blanket behavior with two different codes.

The model is composed by four different regions (Fig. 1). They are, starting from the center:

- plasma chamber;

- sub-critical fission blanket;

— tritium breeding blanket;

— lead-steel shielding.

In this preliminary study, neutrons were assumed to be produced from a DT-plasma, therefore the calculation model considered a monoenergetic isotropic neutron source with an emission rate of $\sim 10^{19} \mathrm{n} / \mathrm{s}$, placed in the center (the plasma chamber). The plasma chamber's volume is $27.5 \mathrm{~m}^{3}$.

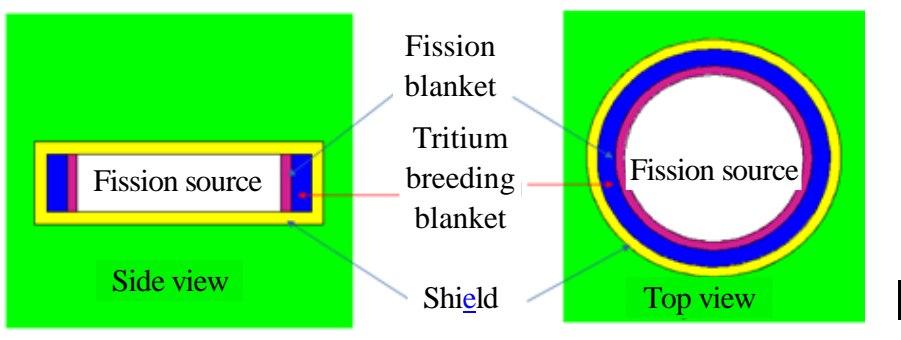

Fig. 1. RZ geometry model

A subcritical fission blanket was defined starting from an elementary fuel cell where fuel pin and lattice cell are set to allow affordable power densities and coolant flow rates. Homogeneous materials compatible with the LFR technology were chosen for the fission blanket, and their homogenization followed the design summarized in Table 1 .

$\mathrm{T}$ a b 1 e 1 . Volume fractions of the fission blanket composition material

\begin{tabular}{c|c}
\hline Material & Volume fraction, $\%$ \\
\hline Fuel (MA-doped MOX) & 27.5 \\
Steel (AIM1) & 8.5 \\
Void (He) & 4.3 \\
Coolant (Pb) & 59.7 \\
\hline
\end{tabular}

In the LFR concept, lead-lithium is used in the blanket as the breeder material, with a composition detailed in Table 2.

$\mathrm{T}$ a b 1 e 2. Volume fraction of the breeding blanket component materials

\begin{tabular}{c|c}
\hline Material & Volume fraction, $\%$ \\
\hline Breeder (PbLi) & 40.0 \\
Steel (AISI 316L) & 60.0 \\
\hline
\end{tabular}

The shielding zone is composed by a mixture of lead and stainless steel (AISI 316L) as shown in Table 3.

$\mathrm{T}$ a $\mathrm{b}$ l e 3 . Volume fraction of the shielding component materials

\begin{tabular}{c|c}
\hline Material & Volume fraction, \% \\
\hline Lead & 35.0 \\
Steel (AISI 316L) & 65.0 \\
\hline
\end{tabular}


Then a reactor with a subcritical $\mathrm{k}_{\text {eff }}$, of about 0.97 was modelled with the ERANOS deterministic code and then loaded in the MCNP code.

Homogenized cross sections for different zones were evaluated with the help of the ERANOS ECCO cell code using the JEFF-3.1.1 [6] nuclear data library with a standard 172 energy group structure, scattering approximation in $\mathrm{P} 3$ and $\mathrm{S} 4$ for angular distribution.

The BISTRO 2D-RZ flux module has been used for both «homogenized» and source calculations.

The neutron source considered was a DT generator that emitted $14 \mathrm{MeV}$ neutrons isotropically and uniformly in the central volume of the geometry.

The same geometry and material composition were used in the MCNP6.1 based simulation. Starting from an isotropic neutron source homogeneously generated inside the "plasma chamber» region, neutrons propagated in other regions. The KCODE card was used to determine the $k_{\text {eff }}$, and the SDEF card was considered as a way to calculate fluxes and reaction rates.

\section{RESULTS}

The results of the effective neutron multiplication factor, $k_{\text {eff }}$, calculation with different reference codes are presented in Table 4.

T a b l e 4. ERANOS vs. MCNP calculation of the effective multiplication factor

\begin{tabular}{c|c|c}
\hline Reference case & $k_{\text {eff }}$ & $\rho$ \\
\hline ERANOS & 0.97054 & -3035 \\
MCNP & 0.98893 & -1119 \\
\hline
\end{tabular}

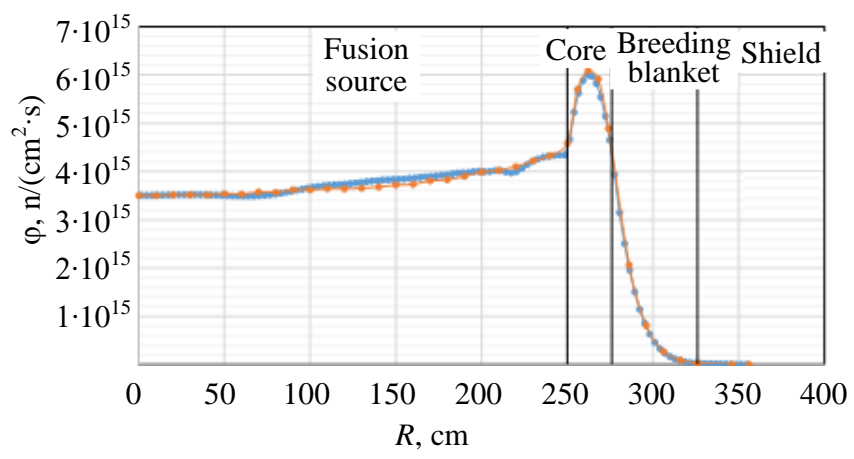

Fig. 2. Comparison of the radial flux distribution as a function of the radial distance from the cylindrical system's center, calculated with the ERANOS (•) and MCNP (॰) codes
Evaluating the source neutrons' importance relative to fission neutrons from the subcritical core is of relevance for an understanding of the subcritical core behavior. The source relative importance, $\varphi^{*}[7]$, is defined as:

$$
\varphi^{*}=\frac{\left(\frac{1}{k_{\mathrm{eff}}}-1\right)}{\left(\frac{1}{k_{s}}-1\right)}
$$

The ERANOS deterministic code assesses the source's importance as: $R=\varphi^{*}=\frac{\frac{\Phi^{*}, S}{S}}{\frac{\Phi^{*}, F \Phi}{F \Phi}}$, where $\Phi^{*}$ — adjoint flux of the homogeneous case; $\Phi$ - direct flux of the inhomogeneous case; $S$ - the external source.

The results are listed below: $k_{\mathrm{eff}}=0.97054 ; k_{s}=0.97403 ; \varphi^{*}=1.121$.

The ERANOS vs. MCNP comparison also covered the neutron flux and some reaction rates along the radial distribution at the middle height of the system. It was chosen to normalize all the results obtained to the ERANOS value in the center of the geometry. Comparison of the radial flux distributions, calculated with the ERANOS and MCNP codes (Fig. 2) shows a good agreement for the whole system. 
Several reaction rates derived by the two codes were compared. Fission rates were calculated using ${ }^{235} \mathrm{U},{ }^{238} \mathrm{U}$ and ${ }^{241} \mathrm{Am}$, with the results shown in Figs. 3-5.

The behavior of the ${ }^{235} \mathrm{U}$ fission reaction rate in the fission blanket zone shows some discrepancies between the two codes, this could reflect the difference for $k_{\text {eff }}$ value presented in Table 3 .

Comparison of the ${ }^{238} \mathrm{U}$ fission reaction rate radial distributions (see Fig. 4), calculated with the two codes, suggests a good agreement for the whole fission zone.

In the case of ${ }^{241} \mathrm{Am}$, fission rate radial distributions have a traverse similar to ${ }^{238} \mathrm{U}$ 's (see Fig. 5), and one can see a good agreement between results obtained with the two codes.

Then, the rates of capture reactions involving ${ }^{237} \mathrm{~Np}$ and ${ }^{238} \mathrm{U}$, as well as ${ }^{6} \mathrm{Li}(n, \alpha)$ were analyzed and compared (Figs. 6-8).

There are notable discrepancies in the behavior of the ${ }^{237} \mathrm{~Np}$ capture rate radial sampling (see Fig. 6) in the fission blanket zone, simulated with the two codes, which call for an explanation.

Discrepancies similar to those found for ${ }^{237} \mathrm{~Np}$ are revealed for the ${ }^{238} \mathrm{U}$ capture rate in Fig. 7, although in the latter case the study is in progress.

The comparison between the two codes for the ${ }^{6} \mathrm{Li}(n, \alpha)$ rate radial distributions, in the breeding blanket zone, shows a very good agreement along all the radial direction (see Fig. 8).

\section{CONCLUSIONS}

The coupling of a subcritical blanket with a fusion source, like in FFHS, may allow the fundamental problem of disposing of long-lived radioactive waste from the back end of the fuel cycle to be approached.

A simplified Fusion-Fission Hybrid System (FFHS) model could allow to study and evaluate some important parameters using different calculation methodologies.

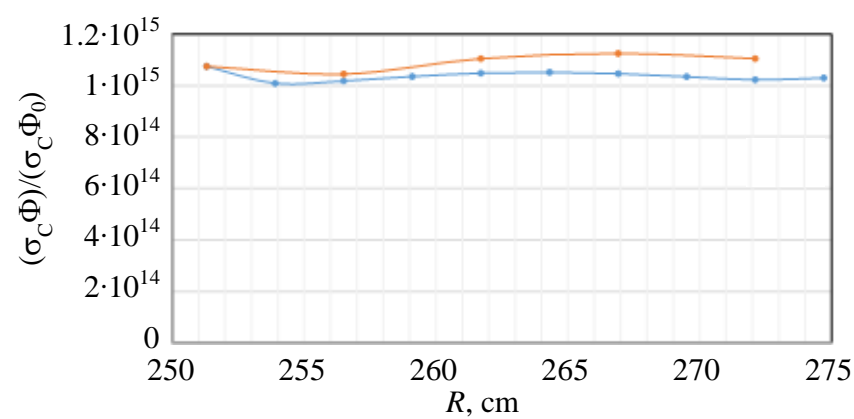

Fig. 7. Comparison of the ${ }^{238} \mathrm{U}$ capture rate radial distribution as a function of the radial distance from the cylindrical system's center, calculated with the ERANOS (•) and MCNP (॰) codes

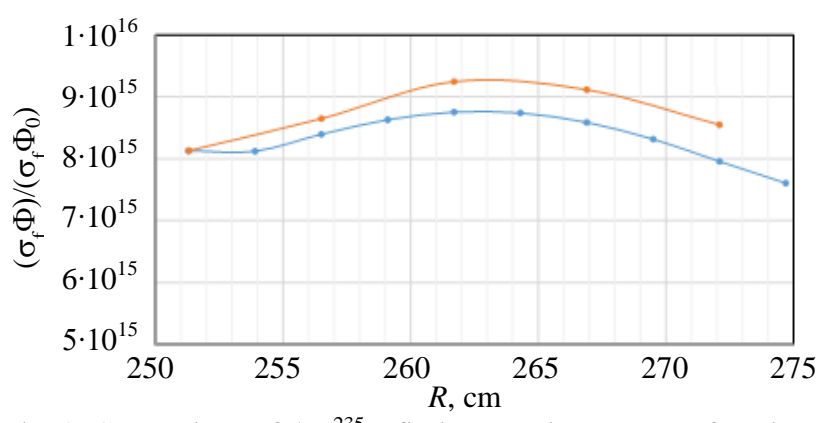

Fig. 3. Comparison of the ${ }^{235} \mathrm{U}$ fission reaction rate as a function of the radial distance from the cylindrical system's center, calculated with the ERANOS (॰) and MCNP (॰) codes

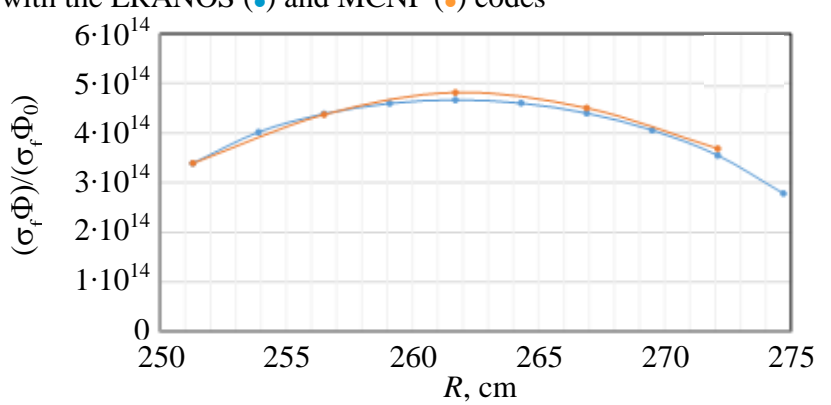

Fig. 4. Comparison of the ${ }^{25 \gamma} U$ fission rate radial distribution as a function of the radial distance from the cylindrical system's center, calculated with the ERANOS (॰) and MCNP (॰) codes

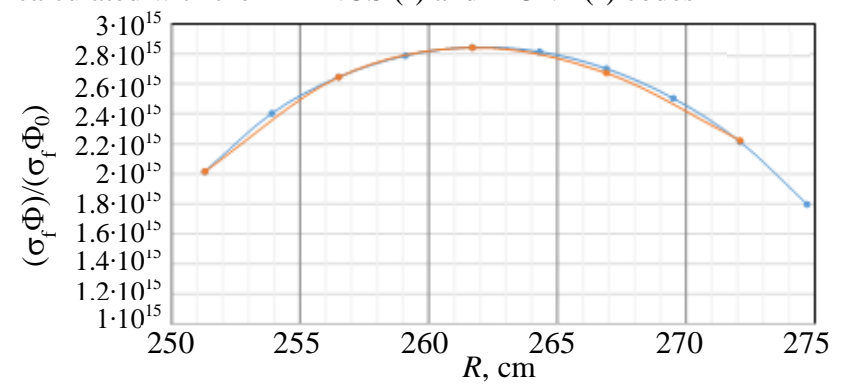

Fig. 5. Comparison of the ${ }^{241} \mathrm{Am}$ fission reaction rate as a function of the radial distance from the cylindrical system's center, calculated with the ERANOS $(\bullet)$ and MCNP $(\bullet)$ codes

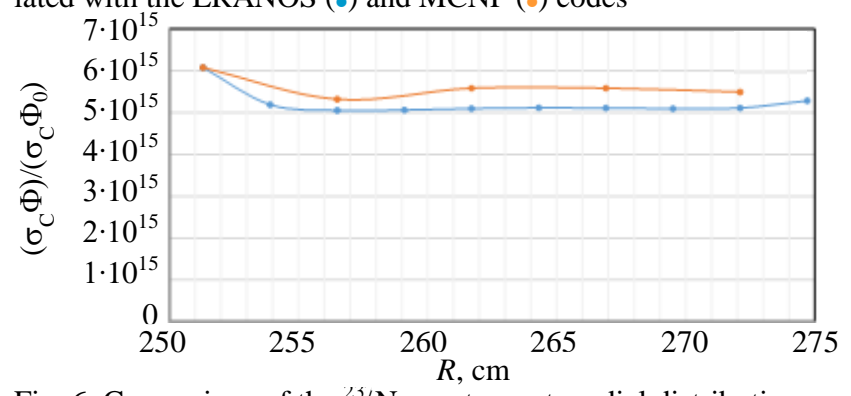

Fig. 6. Comparison of the ${ }^{25} \mathrm{~Np}$ capture rate radial distribution as a function of the radial distance from the cylindrical system's center, calculated with the ERANOS (॰) and MCNP (॰) codes

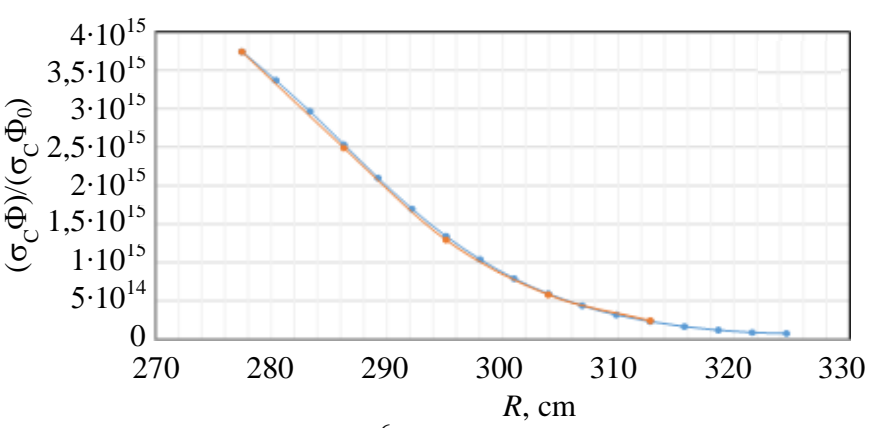

Fig. 8. Comparison of the ${ }^{6} \mathrm{Li}$ capture rate radial distribution as a function of the radial distance from the cylindrical system's center, calculated with the ERANOS (॰) and MCNP (॰) codes 
The simplified RZ model developed in this work was analyzed by both deterministic and Monte Carlo calculations, the analysis was focused on some preliminary parameters, such as the neutron multiplication factor and fluxes and the radial distribution of some reaction rates. This preliminary comparison yields some evidence of a fairly good agreement between the Monte-Carlo and deterministic codes.

There are some differences between the $k_{\text {eff }}$ results and consequently for flux absolute values, which fact calls for further and more in-depth research and subsequent verification.

A full agreement between these results will allow the deterministic code to be useful in performing some important evaluations concerning the FFHSs.

\section{REFERENCES}

1. Bethe H.A. The fusion hybrid. - Phys. Today, 1979, vol. 32 (5), p. $44-51$.

2. Salvatores M. Physics features comparison of TRU burners: fusion/fission hybrids, accelerator-driven systems and low conversion ratio critical fast reactors. - Annals Nucl. Energy, 2009, vol. 36, p. 1653-1662.

3. Gandini A. Generalized Perturbation Theory (GPT) Methods. A Heuristic Approach. - In: Advances in Nuclear Science and Technology, vol. 19, J. Lewins and M. Becker Eds., Plenum Publishing Corporation, New York, 1987.

4. Goorley T. et al. Initial MCNP6 release overview. - Nuclear Technology, 2012, vol. 180, p. 298 -315.

5. Rimpault G., Plisson D., Tommasi J., Jacqmin R., Rieunier J.-M., Verrier D., Biron D. The ERANOS code and data system for fast reactor neutronic analyses. - In: Intern. Conf. PHYSOR, Seoul, Korea, 2002.

6. The JEFF-3.1.1 Nuclear Data Library, JEFF Report 22, Validation Results from JEF-2.2 to JEFF-3.1.1- OECD NEA 2009, ISBN 978-92-64-99074-6.

7. Gandini A., Salvatores M. The physics of subcritical multiplying systems. - J. of Nuclear Science and Technology, 2002, vol. 39:6, p. 673 - 686; DOI: 10.1080/18811248.2002.9715249.

\section{AUTHORS}

Fabio Panza, Researcher, PhD; ENEA Dipartimento Fusione e Tecnologie per la Sicurezza Nucleare — Divisione Tecnologie, Impianti e Materiali per la Fissione Nucleare, Roma, Italy; Istituto Nazionale di Fisica Nucleare, Sezione di Genova, Genova, Italy fabio.panza@enea.it

M. Carta; Dipartimento Fusione e Tecnologie per la Sicurezza Nucleare — Divisione Tecnologie, Impianti e Materiali Per la Fissione Nucleare, Roma, Italy;

A. Cemmi; ENEA Dipartimento Fusione e Tecnologie per la Sicurezza Nucleare — Divisione Tecnologie, Impianti e Materiali Per la Fissione Nucleare, Roma, Italy; Istituto Nazionale di Fisica Nucleare — Sezione di Roma Tre, Roma, Italy

N. Cherubini; ENEA Dipartimento Fusione e Tecnologie per la Sicurezza Nucleare — Divisione Tecnologie, Impianti e Materiali Per la Fissione Nucleare, Roma, Italy

V. Fabrizio; ENEA Dipartimento Fusione e Tecnologie per la Sicurezza Nucleare — Divisione Tecnologie, Impianti e Materiali Per la Fissione Nucleare, Roma, Italy

L. Falconi; ENEA Dipartimento Fusione e Tecnologie per la Sicurezza Nucleare — Divisione Tecnologie, Impianti e Materiali Per la Fissione Nucleare, Roma, Italy

F. Filippi; ENEA Dipartimento Fusione e Tecnologie per la Sicurezza Nucleare — Divisione Tecnologie, Impianti e Materiali Per la Fissione Nucleare, Roma, Italy ; Istituto Nazionale di Fisica Nucleare - Laboratori Nazionali di Frascati, Frascati, Italy

G. Grasso; ENEA Dipartimento Fusione e Tecnologie per la Sicurezza Nucleare — Divisione Sicurezza e Sostenibilità del Nucleare, Bologna, Italy

F.P. Orsitto; ENEA Dipartimento Fusione e Tecnologie per la Sicurezza Nucleare — Divisione Tecnologie, Impianti e Materiali Per la Fissione Nucleare, Roma, Italy

V. Peluso; ENEA Dipartimento Fusione e Tecnologie per la Sicurezza Nucleare — Divisione Sicurezza e Sostenibilità del Nucleare, Bologna, Italy 